\title{
Variations in structure of estuarine fish communities in relation to abundance of submersed vascular plants
}

\author{
L. Lubbers ${ }^{1}$, W. R. Boynton ${ }^{2, *}$, W. M. Kemp ${ }^{3}$ \\ ${ }^{1}$ Maryland Department of Natural Resources, Tawes State Office Building, Annapolis, Maryland 21401, USA \\ ${ }^{2}$ University of Maryland, Center for Environmental Estuarine Studies, Chesapeake Biological Laboratory, Box 38, Solomons, \\ Maryland 20688, USA \\ ${ }^{3}$ University of Maryland, Center for Environmental and Estuarine Studies, Horn Point Environmental Laboratory, Box 755 , \\ Cambridge, Maryland 21613, USA
}

\begin{abstract}
Fish communities and other ecological variables were sampled for 6 mo (May to October) in successive years $(1979,1980)$ at vegetated and non-vegetated areas in 2 distinctively different littoral zones (an open bay and a protected cove) of mid-salinity Chesapeake Bay, USA. Fish abundance, biomass and species richness were higher in vegetated areas at both sites, and were significantly correlated with macrophyte biomass. Diel patterns of fish abundance varied, but highest catches generally occurred at dusk or at night. At one sampling site fish assemblages were dominated by smaller individuals in the vegetated area, suggesting an attraction of juveniles to macrophyte beds for food or refuge from predation. Larger piscivorous fish, which were also caught in greater numbers in vegetated areas, may have been attracted there by higher densities of forage fish. At the cove site the biomass of Paleomonetes $\mathrm{sp}$. was comparable to that of the fish community towards the end of the plant growing season. Benthic infauna were also more abundant in vegetated areas at both sites, and stomach analyses indicated these organisms to be the dominant food resources for common fishes. Diets were generally non-selective in non-vegetated areas while highly selective for epiphytic fauna in macrophyte beds. Fish stomachs were also significantly fuller in vegetated areas, indicating generally greater feeding success. Fish production varied among major species but was higher overall at vegetated areas, following the seasonal patterns of primary production. Most of the differences in fish production between areas were attributable to higher instantaneous growth rates rather than higher biomass. It appears that the greater abundance and species richness of fish assemblages in vegetated areas of this region of Chesapeake Bay resulted from the attractiveness of these habitats as rich sources of preferred foods.
\end{abstract}

\section{INTRODUCTION}

Over the last 2 decades there have been numerous reports describing the littoral zone fish communities associated with beds of submersed vascular plants (e.g. Kikucki 1974, Orth et al. 1984, Pollard 1984). In general, such studies have concluded that these habitats support relatively diverse and abundant fish communities (Adams 1976a, Robertson 1980). Fish standing stocks often exhibit strong positive correlations with plant biomass (Stoner 1983, Robertson 1984, Rozas \& Odum 1987), and a few studies have shown that natural and experimental reductions in macrophyte biomass

\footnotetext{
- Addressee for correspondence
}

can lead to decreased abundance of fish populations (Whitfield 1984, Wiley et al. 1984).

Several mechanisms have been suggested to explain the relatively higher abundance of fish populations in submersed plant beds. These include: enhanced refuge from predation; increased availability of food, especially for juvenile fish; and general habitat preference. Many studies have illustrated the dependence of fish diets on the rich macroinvertebrate communities inhabiting macrophyte beds (Brook 1977, Robertson 1980, 1984, Livingston 1982, Bell \& Harmelin-Vivien 1983, Huh \& Kitting 1985). In some cases it appears that the physical structure of plant leaves, stems, roots and rhizomes provides sufficient protection to allow these macroinvertebrates to thrive (Heck \& Thoman 1984, 
Summerson \& Peterson 1984). In other situations it may be more a simple matter of habitat preference which leads to the dense invertebrate populations in macrophyte beds (Bell \& Westoby 1986). Experimental information available to elucidate the role of macrophyte physical structure, as a fish refuge from predation, suggests that plant structural complexity contributes to decreased fish mortality (Savino \& Stein 1982, Stoner 1983, Orth et al. 1984, Rozas \& Odum 1988). A few investigations have quantitatively assessed the importance of submersed plant beds as sources of food for fish production, by comparing either food availability versus fish requirements (Robertson 1984), or fish growth rates in plant beds versus those in other habitats (Weinstein 1983).

Most studies of fish communities in submersed plant habitats have been conducted in marine or freshwater environments, with relatively less attention to brackish areas. Chesapeake Bay, USA, is a large estuary formerly inhabited by dense beds of submersed vascular plants which have recently experienced major declines in abundance (Kemp et al. 1983a, Orth \& Moore 1983). Conclusions concerning variations in fish abundance in this system, in relation to the biomass of submersed macrophytes, vary. Significantly greater fish abun- dance and diversity have been reported in high-salinity vegetated habitats of the lower Bay (Orth \& Heck 1980), but no differences in fish communities were observed between areas of regetated and bare sediment in a mid-salinity region of the Bay (Heck \& Thoman 1984).

We present the results of fish community studies at 2 sites with different hydrodynamic regimes described previously by Kemp et al. (1984). We compare fish community structure in vegetated and non-vegetated areas at each site, and relate variations in fish abundance and diversity to spatial and temporal differences in submersed plant biomass and standing stocks of macroinvertebrate populations. Potential mechanisms controlling these patterns are considered by comparing food habits and production rates of important fishes of vegetated and non-vegetated areas at one site.

\section{METHODS}

Description of study sites and sampling frequency. Two sampling sites in the middle reaches of Chesapeake Bay were selected for this study (Fig. 1). One was in a large, exposed, well-flushed bay near

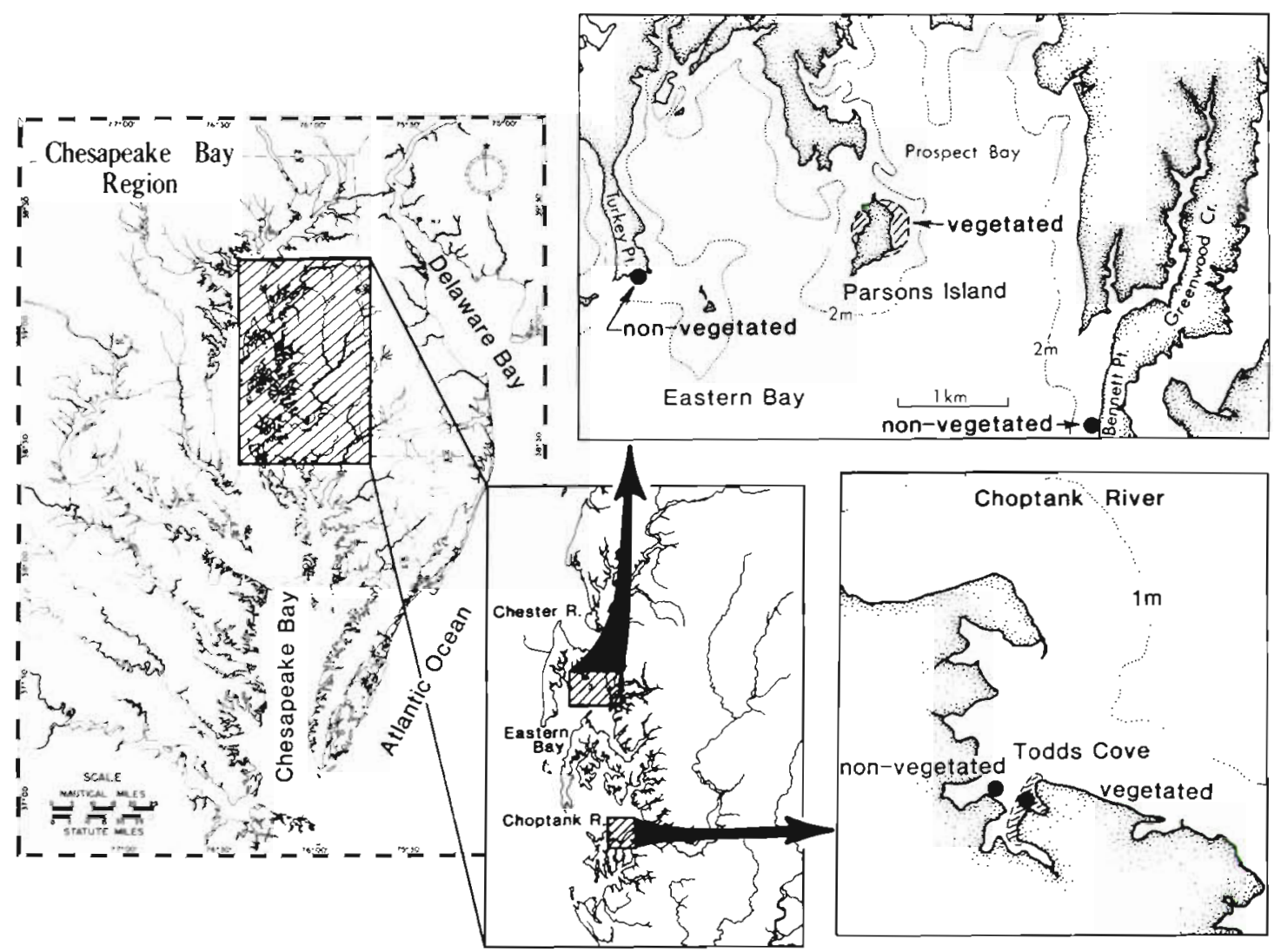

Fig. 1. Location of sampling sites (vegetated and non-vegetated areas) in the mid-salinity region of northern Chesapeake Bay, 
Parsons Island $\left(38^{\circ} 54.45^{\prime} \mathrm{N}, 76^{\circ} 14.90^{\prime} \mathrm{E} ; 1979\right)$. The vegetated area at this site covered about $15 \mathrm{ha}$, with a depth range (MLW) of about 0.4 to $2.0 \mathrm{~m}$. The dominant, submersed, vascular plant was Potomogeton pectinatus, but Ruppia maritina, Zanichellia pulustrus and $P$. perfoliatus were also present. The non-vegetated area, separated from the macrophyte bed by 2 to $3 \mathrm{~km}$ and a deep channel, was characterized by similar exposure to waves and tidal flushing (range $0.5 \mathrm{~m}$ ), with comparable fine-grained sand sediments. In the following year (1980) a second study site was established in Todds Cove on the Choptank River (38 36.85' N, $76^{\circ} 14.00^{\prime} \mathrm{E}$ ). This site was far more protected from wave action, with reduced flushing due to a sand bar at the entrance to the cove. The plant community here covered an area of about 3 ha and extended from the shoreline over a depth range of 0.5 to $1.5 \mathrm{~m}$ (MLW), and sediments were predominately muddy-sands. The dominant plant species was $P$. perfoliatus, but $R$. maritima, $Z$. palustris and Elodea canadensis were present at lower abundance levels early in the growing season. The non-vegetated area at Todds Cove, which was located about $300 \mathrm{~m}$ west of the plant bed, had similar depth and hydrographic characteristics, but sediments appeared to be sandier.

Studies at all sites and in both years (1979, 1980) were conducted from May through October. This time interval encompassed the period in which aboveground plant biomass was present, from spring emergence through fall senescence. Sampling was conducted on a monthly basis and 3 to $5 \mathrm{~d}$ were required to complete all sampling activities. Specific locations for sampling quadrants and net deployments were moved each month to avoid possible artifacts of repeated sampling in one location.

Physical and chemical measurements. The areal extent of submersed vegetation at each site was estimated from low-level $(1000 \mathrm{~m})$ color infra-red aerial photographs taken during the middle of each growing season. Temperature and salinity were measured using a Beckman induction salinometer and thermistor. Attenuation of irradiance $(400$ to $700 \mathrm{~nm})$ was determined from vertical water column profiles using an LICOR quantum sensor.

Fish sampling. Several gear types were evaluated prior to the beginning of the sampling program and selection of gear types was guided by these results as well as by ease of use. Simultaneous fish collections (triplicate samples) were made in vegetated areas using a portable drop-net $\left(16 \mathrm{~m}^{2}\right)$, beach-seine $(15 \mathrm{~m}$ length), otter-trawl (4.9 m mouth width) and modified haul-seine (31 $\mathrm{m}$ length). The haul-seine and drop-net collected the highest biomass of fishes $(\bar{x}=20.8$ and $30.6 \mathrm{~g}$ wet wt $\mathrm{m}^{-2}$, respectively). Beach-seine and otter-trawl catches were lower by factors of about 5 and
10, respectively. We selected the haul-seine over the drop-net for routine sampling because it was much easier to use. Similarly, simultaneous grass-shrimp collections were made with the haul-seine and a push-net (1.8 $\mathrm{m}$ width). Catches using the push-net were 7 to 19 times higher than those with the seine, and therefore the push-net was selected for routine use. We did not conduct comparative evaluations of the gill-nets but did adopt a mesh size $(7.6 \mathrm{~cm})$ commonly used for sampling larger fishes.

Fish were sampled (in triplicate) at monthly intervals in the early evening. Haul-seines (length $=31$ or $107 \mathrm{~m}$; height $=1.8 \mathrm{~m}$; mesh $=0.6$ or $3.8 \mathrm{~cm}$ ) were equipped with collection bags ( $1.8 \mathrm{~m}$ long, $1.8 \mathrm{~m}$ wide) attached to one end of the seine. A leadline and chain also were attached to the bottom edge of the seine and collection bag, respectively, to reduce escapement. Each seine was deployed by attaching the end with the collection bag to a pole previously driven into the sediments. The net was then rapidly spread in a circle (80 or $906 \mathrm{~m}^{2}$ ). Once the sampling area was enclosed, the free-end of the net was then pulled past the pole until only the collection bag remained free, at which time the chain at the bottom of the bag was pursed and the sample transferred to a small boat. The design of the seine and the sampling technique is similar to that described by Kjelson \& Johnson (1974) for sampling fish populations in offshore estuarine habitats.

Larger, highly mobile fish were collected using gillnets (length $=30$ to $40 \mathrm{~m}$; height $=2 \mathrm{~m}$; mesh size $=$ $7.6 \mathrm{~cm}$ ). Nets were deployed along the edges of the plant community and at similar depths at the nonvegetated area for up to $24 \mathrm{~h}$. Fish were collected and the nets cleaned every 4 to $6 \mathrm{~h}$ during deployments. We did not observe evidence of crab predation on captured fish (i.e. partially consumed fish) although some such losses may have occurred. Fish samples from all gear types were preserved in formalin and later identified to species, weighed, and measured. All fish biomass data are reported as preserved wet weight (ww). Sub-samples representative of the size-class structure of each abundant species were saved for subsequent stomach. analyses.

At the Parsons Island areas, we conducted diel studies of fish abundance in June and September. Samples were collected at dawn, noon, dusk and midnight using the 31 and $107 \mathrm{~m}$ haul-seines. Collections were treated as previously described except that no stomach analyses were conducted.

Food resources. At Todds Cove Paleomonetes sp. were sampled using a push-net which consisted of a small seine ( $1.8 \mathrm{~m}$ width, $0.6 \mathrm{~cm}$ mesh) with a collecting bag in the middle. The ends of the seine were connected to poles which were used to push the net forward for 4 to $10 \mathrm{~m}$, after which the entire net was 
quickly lifted into a boat. Samples were taken in triplicate and preserved in formalin. Concurrent studies indicated that neither the push-net nor the haul-seine were effective in the collection of Callinectes sapidus, and hence we do not report data for that species (Kemp et al. 1983b).

Standing stocks of vascular plant shoot-biomass were obtained by harvesting the material enclosed within $0.25 \mathrm{~m}^{2}$ quadrats. During each sampling period 6 replicate samples were collected from each vegetated area. After collection, samples were sorted to species and dried $\left(60^{\circ} \mathrm{C}\right)$ to constant weight. Epiphytic solids never comprised more than $2 \%$ of dried vascular-plant biomass.

Benthic macrofaunal abundances were obtained using a hand-operated piston corer ( $8 \mathrm{~cm}$ diameter) which sampled to a depth of $30 \mathrm{~cm}$. Seven cores were collected from all areas on each sampling date. Individual samples were sieved through $0.5 \mathrm{~mm}$ mesh screen, stained with rose bengal and preserved in $10 \%$ buffered formalin. Samples were sorted to species, counted and measured. Biomass estimates were based on numerical abundance, size and length-weight relationships.

Epiphytic fauna were collected in triplicate using a small net $(0.5 \mathrm{~mm}$ mesh) attached to a rigid frame, the open end of which could be gently lowered over the plants to the sediment surface covering an area of $0.1 \mathrm{~m}^{2}$. Plants were cut off at the sediment surface and the open end of the net closed with a drawstring. The contents of the net were washed into a bottle and preserved in $10 \%$ buffered formalin. Animals were separated from plant material, sorted to species, counted and weighed.

Fish stomach analyses. The stomachs examined came from fish collected with the $31 \mathrm{~m}$ haul-seine at the Parsons Island site. Individuals of several species were selected to represent the size-class structure of the population at the time of sampling. All food items found in stomachs were identified to species or the nearest taxon possible, counted and measured, and the total weight of each food-item group estimated from previously determined length-dry weight regressions (Kemp et al. 1983b). Diet was then determined as percent (by weight) of food items grouped into 7 frequently occurring and 11 occasionally occurring categories. Data for each species were grouped according to size class and pooled for the June to September period.

A comparison of food habits versus food availability was developed using a 'selectivity coefficient' (SC) which for a given food item was taken as the ratio of percent (wt) in the diet to percent (wt) present in the environment (Royce 1972). Finally, the relative extent of feeding success of fishes in littoral habitats was assessed using an 'index of fullness' (FI) for stomachs
(Royce 1972). Estimates of percent fullness for stomachs and guts of fish collected in the June seining at Parsons Island were obtained by comparing weight of stomach (or gut) contents for a given fish to the maximum weight of contents recovered for that species and size class of fish.

\section{RESULTS AND DISCUSSION}

\section{The physical environment}

Temperature and salinity patterns during the study periods were similar at vegetated and non-vegetated areas at each study site. Water temperature ranged from 13 to $28^{\circ} \mathrm{C}$ and salinity from 7 to $11 \mathrm{ppt}$, and no unusual departures were noted during the measurement period although May and October water temperatures were higher in 1980 at Todds Cove (Fig. 2).

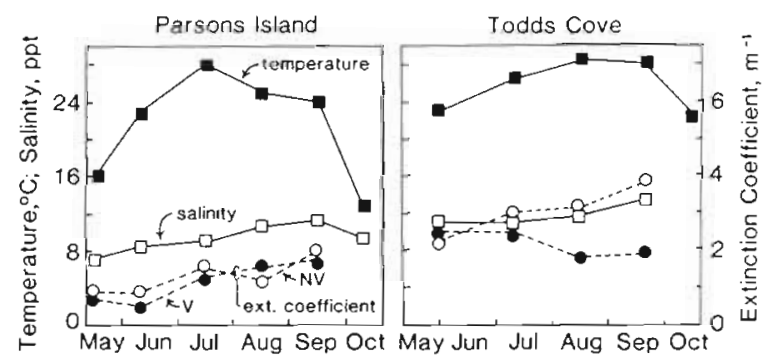

Fig. 2. Mean monthly temperature $\left({ }^{\circ} \mathrm{C}\right)$, salinity (ppt) and extinction coefficient $\left(\mathrm{m}^{-1}\right)$ data from the Parsons Island and Todds Cove study sites. Values from vegetated ( $V$ ) and nonvegetated (NV) areas are shown separately for extinction coefficient data; other data were averaged for vegetated and non-vegetated areas as differences were small

There were, however, some differences among sites relative to water clarity. There was an increase in turbidity at both Parsons Island areas through the study period, with little difference between vegetated and non-vegetated areas. Since the Parsons Island areas were more exposed to wave action, the influence of submersed vascular plants in controlling resuspension of bottom sediments may have been less effective (Ward et al. 1984). Turbidity levels at Todds Cove were higher than those at Parsons Island but there was a pronounced increase in water clarity associated with the vegetated area during the summer and early fall.

\section{Diel patterns of fish abundance}

In June at the Parsons Island vegetated area, lowest numerical abundance occurred at dawn and highest at dusk or midnight for both sampling gears (Fig. 3). Rela- 
Fig. 3. Relative abundance estimates (no. ind. $\mathrm{m}^{-2}$ ) of fish sampled at dawn, mid-day, dusk, and mid-night at the Parsons Island study site in June and September Collections were made at both vegetated and non-vegetated areas. Gear types included: (A) $31 \mathrm{~m}$ haul-seine for collection of smaller fish, and (B) $107 \mathrm{~m}$ haul-seine for collection of larger species
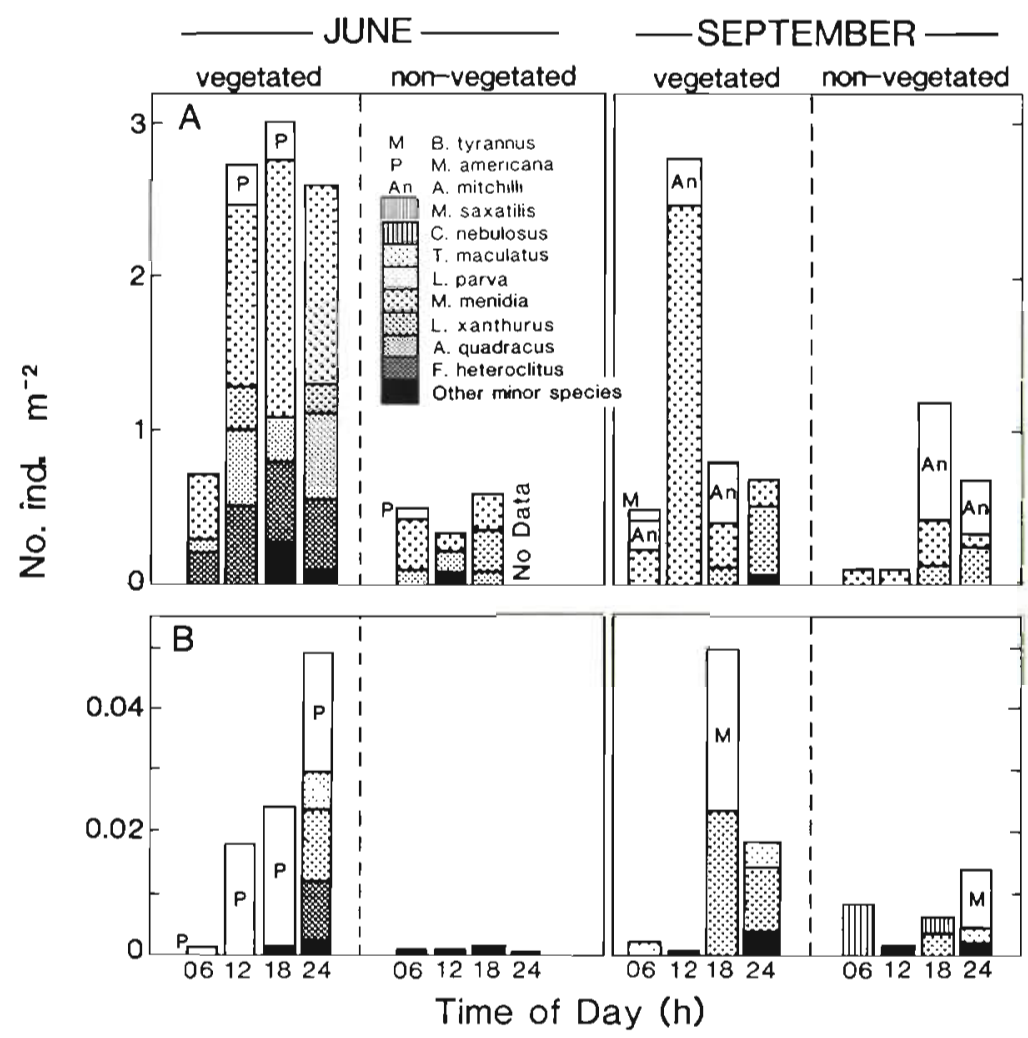

tively high abundance estimates were also occasionally obtained at midday, especially with the smaller haulseine. Abundance was low throughout the diel period at the non-vegetated area. In September, diel patterns were less clear, but highest catches continued to occur at dusk or midnight (except for a large catch of silversides at midday). Although diel trends were variable, the tendency towards greater abundance at night was similar to those previously reported (Adams 1976a, Heck \& Orth 1980a, Leber \& Greening 1985, Gray \& Bell 1986)

Species composition was similar throughout diel periods, indicating that diel changes were not the result of different species utilizing littoral areas at different times (e.g. Robertson 1980, Robblee \& Zieman 1984). Other studies have reported variations in species composition occurring throughout a diel cycle (Robertson 1980, Bell \& Harmelin-Viviens 1982, 1983). Most of the fish at our study sites were typical of littoral areas, with little diel movement evident, but apparently greater susceptibility to capture at night.

\section{Fish community structure}

A total of 30 fish and 6 macroinvertebrate species were collected from all areas. Most species were com- mon estuarine types in both the vegetated and nonvegetated areas (Table 1), although a few rare species were collected (e.g. Synodus foetens). Our estimates of total species are higher than those previously reported for the Parsons Island site (Heck \& Thoman 1984) and similar to those at tidal fresh sites in Chesapeake Bay (Serafy et al. 1988). It appears that fish assemblages at vegetated estuarine sites have fewer species than in higher salinity habitats (Harmelin-Vivien 1983, Stoner 1983, Pollard 1984).

During the summer period (June to September), total number of fish species (species richness) was significantly greater in the vegetated areas of both sampling sites (ANOVA, $n=12, p<0.05$ ). The differences in number of species between macrophyte beds and nonvegetated areas were similar in both cases, although the Todds Cove site had greater species richness. Mean ( $\pm \mathrm{SE}$ ) values for number of species encountered during the summer were $10.5( \pm 1.0)$ and $6.3( \pm 1.3)$ for vegetated and non-vegetated sites at Parsons Island, respectively, and $12.5( \pm 0.7)$ and $8.3( \pm 2.2)$ at Todds Cove. This pattern of greater fish species richness in vegetated habitats is similar to that reported for areas in lower Chesapeake Bay (Orth \& Heck 1980, Weinstein \& Brooks 1983) but contrasts with the absence of a macrophyte effect observed in coastal regions of Florida (Stoner 1983). 
Table 1 Fishes and macroinvertebrates collected at Parsons Island and Todds Cove study sites in northern Chesapeake Bay in 1979 and 1980

\begin{tabular}{|ll|}
\hline Scientific name & Common name \\
\hline FlSH & \\
Anchoa mitchilli & \\
Anguilla rostrata & Bay anchory \\
Apeltes quadracus & American eel \\
Brevoortia tyrannus & Four-spine stickleback \\
Carcharhinus leucas & Atlantic menhaden \\
Cynoscion nebulosus & Bull shark \\
Cyprinus carpio & Spotted seatrout \\
Cyprinodon variegatus & Carp \\
Dorosoma cepedianum & Sheepshead minnow \\
Fundulus diaphanus & Gizzard shad \\
Fundulus heteroclitus & Banded killifish \\
Gobiosoma bosci & Mummichog killifish \\
Lepomis gibbosus & Naked goby \\
Leiostomus xanthurus & Pumpkinseed \\
Lucania parva & Spot \\
Membras martinica & Rainwater killifish \\
Menidia beryllina & Rough silversides \\
Menidia menidia & Inland silversides \\
Morone americana & Atlantic silversides \\
Morone saxatilis & White perch \\
Opsanus tau & Striped bass \\
Paralichthys dentatus & Toad fish \\
Pomatomus saltatrix & Summer flounder \\
Pseudopleuronectes annericanus & Bluefish \\
Rhinoptera bonasus & Cownosed ray \\
Strongylara marina & Atlantic needlefish \\
Syngnathus fuscus & Northern pipefish \\
Synodus foetens & Inshore lizard fish \\
Trinectes maculatus & Hogchoker \\
Tylosurus acus & Agujon (needlefish) \\
MACRoINVERTEBRATES & \\
Callinectes sapidus & Blue crab \\
Crangon septimspinosa & Sand shrimp \\
Limulus polyphemus & Horseshoe crab \\
Neomysis americana & Mysid shrimp \\
Paleomonetes intermedius & Grass shrimp \\
Paleomonetes pugio & Grass shrimp \\
& \\
\hline
\end{tabular}

\section{Fish abundance}

Consistent differences and strong seasonal patterns of fish abundance were observed at both study sites (Fig. 4). In the Parsons Island vegetated area, biomass of fish collected using the $31 \mathrm{~m}$ seine ranged from 0.1 (May) to $11.2 \mathrm{~g} \mathrm{ww} \mathrm{m}^{-2}$ (July) and was significantly correlated with temperature $(\mathrm{r}=0.81, \mathrm{n}=6)$ and macrophyte standing stocks (Fig. 5). In the non-vegetated area, the range in biomass was smaller $(0.8$ to $4.5 \mathrm{~g} \mathrm{ww}$ $\mathrm{m}^{-2}$ ), and the relationship between fish biomass and temperature was significant ( $\mathrm{r}=0.75, \mathrm{n}=6$ ) only when menhaden were excluded from the analysis. Abundance and biomass in the vegetated area developed earlier in the year and were significantly higher com- pared to the non-vegetated area (ANOVA, $\mathrm{n}=18, \mathrm{p}$ $<0.05)$. By September, when submersed vascular plant biomass was low, fish abundance and biomass were essentially identical between vegetated and non-vegetated areas. The greater abundance of fishes in the vegetated habitat at Parsons Island contrasts with observations of Heck \& Thoman (1984) based on ottertrawl collections; we suggest that this difference may be attributable to the reduced efficiency of trawls (Kjelson \& Colby 1976, Hartman \& Herke 1987).

Patterns of fish abundance at Todds Cove appeared more complex because of the occasional capture of schooling species such as menhaden (Fig. 4). Correlations of total fish abundance with temperature or macrophyte biomass were not significant. However, if menhaden are excluded, fish biomass at the vegetated area was significantly correlated with temperature ( $\mathrm{r}=$ 0.87, $\mathrm{n}=5, \mathrm{p}<0.05$ ) and macrophyte biomass (Fig. 5). Ranges in total fish biomass at Todds Cove were 9.0 to $104 \mathrm{~g}$ and 4.8 to $12.5 \mathrm{~g} \mathrm{ww} \mathrm{m}^{-2}$ in vegetated and nonvegetated areas, respectively. Fish abundance and biomass in vegetated areas at both sampling sites were similar to those reported for other fish communities in vegetated estuarine and higher salinity habitats (e.g. Hellier 1962, Brook 1977, Orth \& Heck 1980, Robertson 1980, Thayer \& Fonseca 1984, Sogard et al. 1987).

\section{Large mobile fish}

Highest biomass levels of gill-net collections of large fish were in the vegetated area at Parsons Island in July when macrophyte biomass was maximal (Fig. 6). Catches per unit effort were 2 to 4 times higher in vegetated compared to non-vegetated areas in July and August. These results suggest that large mobile fish were attracted to the submersed plant community. Catches were also consistently higher at night than during day; however it is not clear if this indicates greater utilization of macrophyte beds or higher gear efficiency at night, or both (e.g. Leber \& Greening 1985).

Patterns of species occurrence at this site indicated little difference between vegetated and non-vegetated areas. Of the 11 species collected at both sites, 6 were of commercial or recreational value (Hildebrand \& Schroeder 1928). Most literature reports indicate an important role for submersed macrophyte beds regarding economically valuable fish (Thayer \& Fonseca 1984). In Australian coastal areas, some $30 \%$ of fish species in a Posidonia bed were of commercial importance (Burchmore et al. 1984), while feeding for an economically valuable species of whiting was strongly associated with Zostera habitats (Robertson 1977). Our data suggest a similar degree of importance for submersed macrophyte beds in brackish waters. 
Fig. 4. Relative abundance and biomass (no. ind. $\mathrm{m}^{-2}$ and $\mathrm{g} w \mathrm{w} \mathrm{m}^{-2} ; \overline{\mathrm{x}} \pm \mathrm{SE}$ ) of fish species based on triplicated $31 \mathrm{~m}$ haul-seine samples from vegetated and non-vegetated study areas at the Parsons Island and Todds Cove sites. The total number of species collected during each measurement is shown along the $\mathrm{x}$-axis as is the month in which samples were collected. In cases where the number or biomass of specific species was too small to be readily shown in coded form on the bar graph, it was included in the category of Others. The scale of the vertical axis changes between panels. Entries without SE bars were based on either 1 or 2 samples

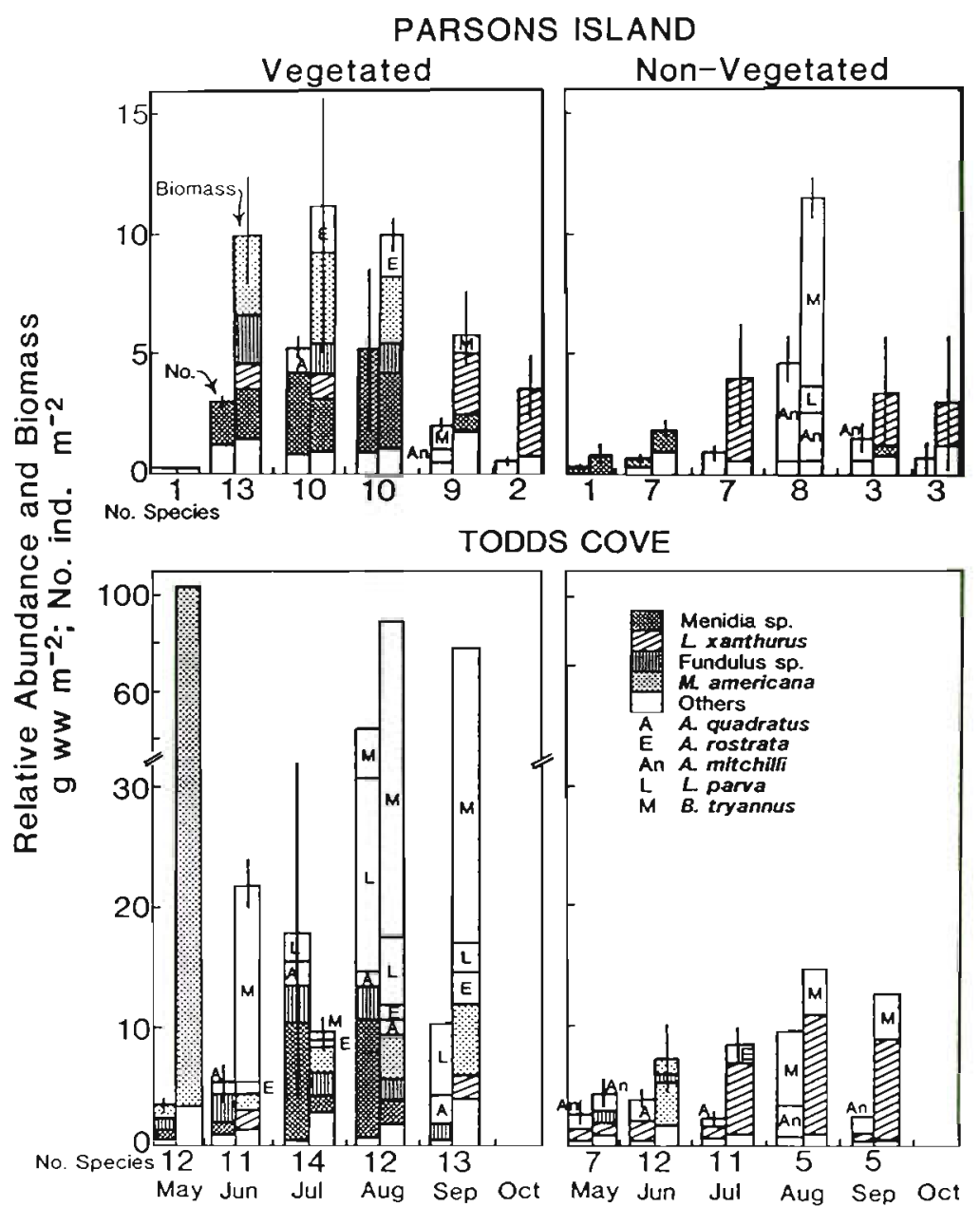

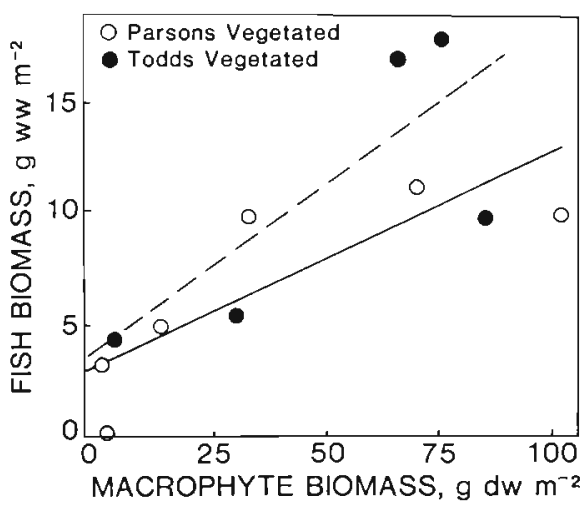

Fig. 5. Scatter plot of fish biomass (31 m seine samples; Brevoortia tyrannus data excluded) versus submersed macrophyte biomass for vegetated areas. For Parsons Island data (continuous line): $\mathrm{n}=6, \mathrm{r}=0.82, \mathrm{y}=0.09 \mathrm{x}+3.39, \mathrm{p}<0.05$. For Todds Cove data (dashed line): $\mathrm{n}=5, \mathrm{r}=0.81, \mathrm{y}=0.14 \mathrm{x}$ $+3.85, p<0.10$

A composite of stomach analyses for such commercially important species as Cynoscion nebulosus, Pomatomus saltatrix and Morone saxatilis indicated that fish comprised 80 to $90 \%$ (by weight) of diets, and that species common to vegetated areas e.g. Leiostomus xanthurus and Menidia menidia, were important dietary items. Since small fish were more abundant in submersed plant beds than bare sediments (Figs. 4 and 6), it is tempting to conclude that large piscivorous fish entered the macrophyte beds in pursuit of forage fish occurring within. However, our sampling was designed to catch large fish at the edges of the bed and hence it remains unclear as to whether large fish entered the bed to feed or remained on the edges and fed on small fish leaving the bed.

\section{Habitat complexity}

A number of features of the sites we examined were consistent with previous findings related to habitat complexity (Heck \& Orth 1980a, Savino \& Stein 1982, Sogard et al. 1987). At both vegetated areas maximum above-ground plant biomass values were similar but plant structure and the seasonal patterns of plant bio- 


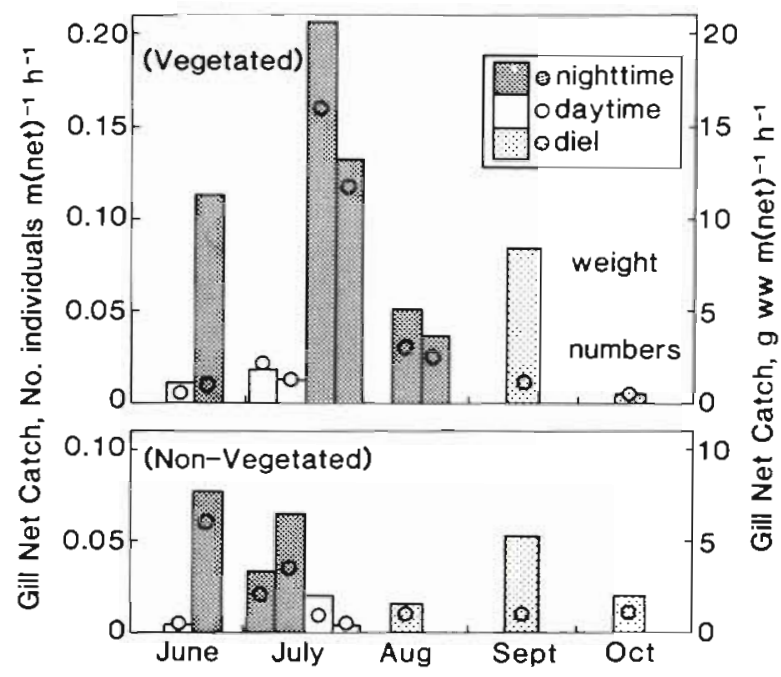

Fig. 6. Relative abundance (no, ind. [circles] and g ww [bars] $\mathrm{m}^{-1}$ of gill-net $\mathrm{h}^{-1}$ ) of fish collected at vegetated and nonvegetated areas at Parsons Island using gill nets. Each vertical bar represents one deployment. Open, darkened and stippled bars and circles represent day, night and diel deployments, respectively

mass were quite different. Potomogeton perfoliatus (dominant at Todds Cove) is heavily branched especially towards the upper portion of the plant and has conspicuous leafy foliage which reached to the surface. $P$. pectinatus (dominant at Parsons Island) has a poorly branched lower stem and filiform leaves, and (at least at Parsons Island) did not extend through most of the water column. Additional features that varied between sites were shoreline morphology (complex at Todds Cove, linear at Parsons Island) and wave action (very slight at Todds Cove). Some of the fish community differences we found between sites are consistent with the notion that complex plant structure and shoreline morphology increases habitat complexity and that wave action can act as a stress. In general, fish speciesrichness and abundance were greater at the Todds Cove vegetated area than at the comparable Parsons Island area, as were abundances of macroinfauna, epifauna and grass shrimp despite the fact that maximum submersed vascular plant biomass was similar between sites. Further, fish and macroinvertebrate abundances at the non-vegetated area at Todds Cove were comparable to, and often higher than, those at the vegetated area at Parsons Island suggesting that complex or sheltered shoreline morphology and reduced wave stress may also play a role in subtly altering the structure of these communities (Sogard et al. 1987).

Finally, we found the mean biomass per individual for the total fish community during the period June to September was almost 4 times higher in the non-vegetated area $\left(3.6 \pm 1.1 \mathrm{~g} \mathrm{ww}\right.$ ind. $\left.{ }^{-1}\right)$ than in the macrophyte bed $\left(1.0 \pm 0.2 \mathrm{~g} \mathrm{ww}\right.$ ind. $\left.{ }^{-1}\right)$ at Todds Cove. At
Parsons Island there was no difference between vegetated and non-vegetated areas suggesting that this site played a less important role as a habitat for very young fishes.

\section{Fish diets and food resources}

In this section we consider the hypothesis that the greater abundance of fish observed in macrophyte beds is associated with increased availability of food resources. We examine first the food habits of selected species, then compare relative abundance of food items in vegetated and non-vegetated areas at Parsons Island, and finally compare aspects of food availability versus feeding habits.

\section{Fish food habits}

Six fish species collected in seine samples were selected for analyses (365 stomachs were examined). Three species (Leiostomus xanthurus, Menidia menidia and Morone americana) were dominant in both vegetated and non-vegetated areas, and 3 species (Apeltes quadracus, Fundulus diaphanus and Anguilla rostrata) were common only in the vegetated area (Fig. 4).

Menidia menidia exhibited the most pronounced differences in food habits between vegetated and nonvegetated areas (Fig. 7). Diets shifted from predominantly epiphytic (insects and fish eggs attached to plant surfaces) to predominantly infaunal (polychaetes and molluscs) foods between vegetated and non-vegetated habitats, respectively. Previous studies in seagrass meadows have reported more varied feeding habits for this species (Carr \& Adams 1973, Adams 1976b, Orth \& Heck 1980).

Leiostomus xanthurus also had different diets in vegetated versus non-vegetated areas for both size classes. In the macrophyte bed, epiphytic and infaunal organisms comprised similar fractions of spot diets although larger individuals appeared to consume fewer polychaetes. Other macrophyte-associated items (shrimp, plant leaves and seeds) were also important. At the non-vegetated area, polychaetes were, by far, the dominant food item, especially for the smaller fish. Food habits for this species at the non-vegetated area were similar to those reported by Homer \& Boynton (1978) for deeper areas of Chesapeake Bay. Although plant material comprised 10 to $15 \%$ of stomach contents for larger individuals, this probably resulted from inadvertent consumption during grazing on epiphytic organisms rather than intentional herbivory (Adams 1976b, Orth \& Heck 1980).

Major food items of Morone americana included 
Fig. 7. Stomach contents of selected fish species collected from vegetated (V) and non-vegetated (NV) sampling areas at the Parsons Island study site. Histograms represent stomach contents as percent weight of specific food items averaged for the May to September period for several size-class intervals. The number of stomachs examined that contained food items is indicated at the top of each histogram
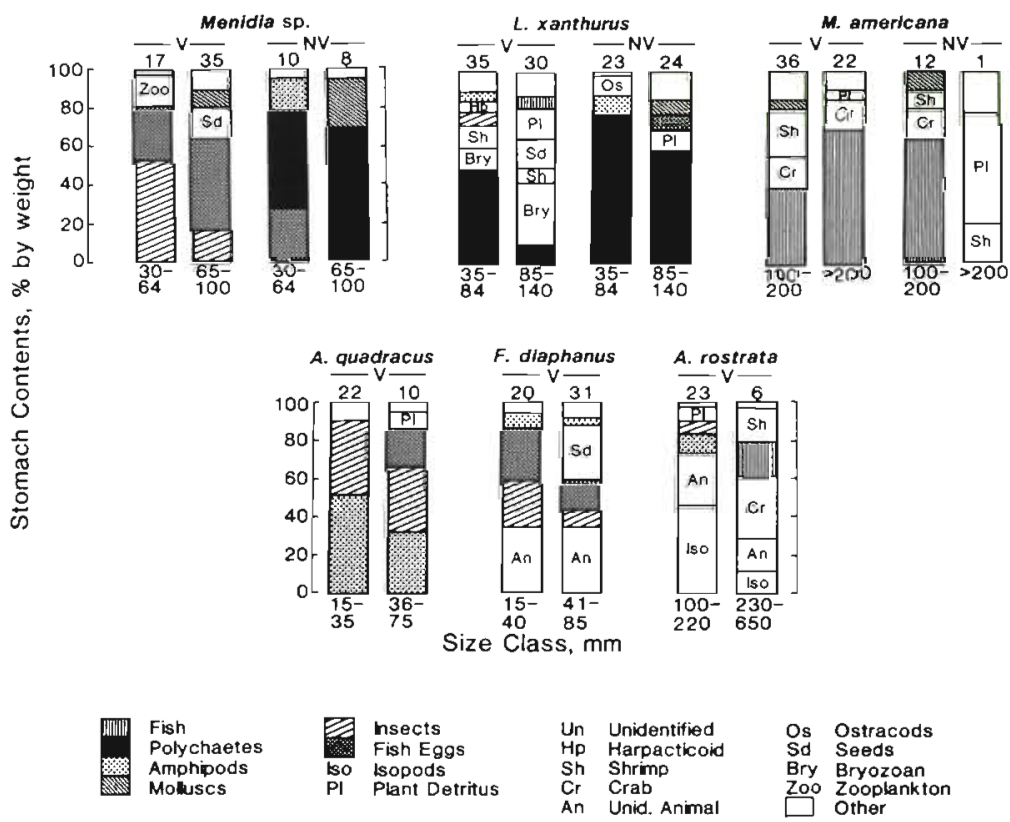
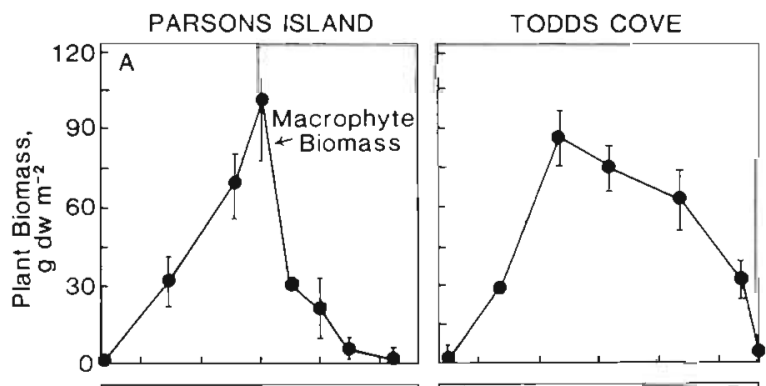

small winter flounder and gobies, blue crabs and grass shrimp in both the vegetated and non-vegetated area. The similarity between areas suggests that this species may move readily between vegetated and non-vegetated areas. The fact that they were more abundant (or more susceptible to capture) in the vegetated area, however, indicates that higher densities of forage fish in macrophyte beds may have been a factor attracting M. americana.

Apeltes quadracus and Fundulus diaphanus fed primarily on epiphytic food items, including amphipods, insects, fish eggs and seeds. There were no substantial shifts in feeding habits between the 2 size groups for those species

Anguilla rostrata fed on a diversity of food items, some of which were abundant in the vegetated area. This species, however, exhibited substantial dietary difference between size classes, where fish smaller than $220 \mathrm{~mm}$ fed on small epiphytic animals and larger individuals (230 to $650 \mathrm{~mm}$ ) preyed on crabs, shrimp and fish (Fig. 7).

\section{Food resources}

Net community primary production in macrophyte beds was 2 to 5 times greater than at non-vegetated areas (Kemp et al. 1984), indicating greater direct or indirect support for food-chains at the vegetated areas. Macrophyte biomass was similar in peak magnitude at both study areas, although mean biomass was higher at Todds Cove, and seasonal patterns and species composition were quite different (Fig, 8A). Plants at Parsons Island (Potomogeton pectinatus) exhibited a distinct

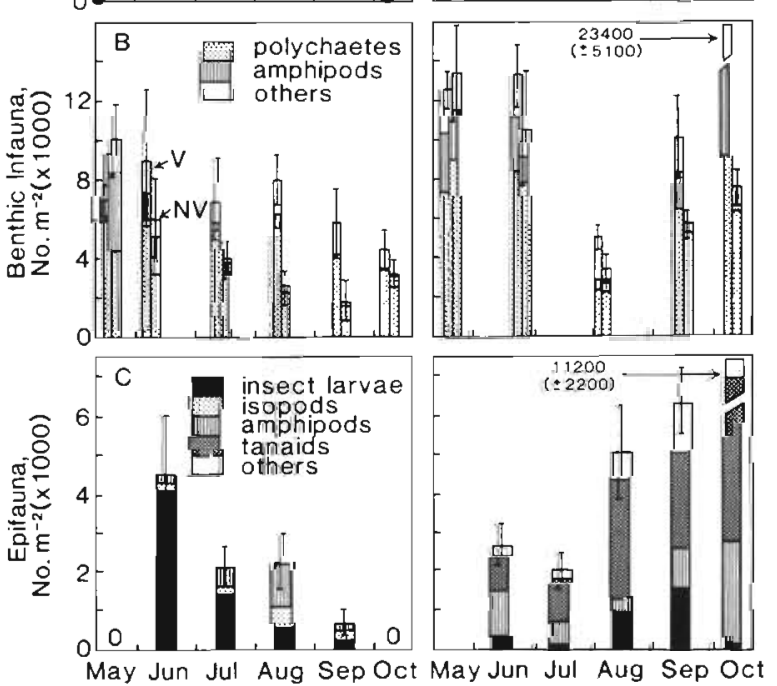

Fig. 8. Mean monthly biomass and abundance data (g dry wt $\mathrm{m}^{-2}$ and no. ind $\mathrm{m}^{-2} ; \overline{\mathrm{x}} \pm \mathrm{SE}$ ) from vegetated (V) and nonvegetated (NV) areas at the Parsons Island and Todds Cove study sites. (A) Macrophyte biomass; (B) macrobenthic infauna (histograms given in pairs comparing contemporaneous measurements at vegetated and non-vegetated areas, respectively): (C) epifauna (vegetated areas only) 
biomass peak in late July, but at Todds Cove high values for macrophyte biomass ( $P$. perfoliatus) persisted from July through September.

During the summer period, abundance of benthic macroinfauna was 30 to $150 \%$ higher at vegetated than non-vegetated areas (Fig. 8B). Total number of species encountered (35) was at the lower end of the range of species richness reported for vegetated sediments, particularly when compared to semi-tropical or tropical regions (Orth 1973, Brook 1977. Stoner 1980, Lewis \& Stoner 1983). Similar patterns of increased infauna abundance associated with macrophytes have been reported previously for both estuarine (Homziak et al. 1982, Lewis \& Stoner 1983) and freshwater systems (Cyr \& Downing 1988). Polychaetes dominated infaunal abundance and biomass at all sites, Heteromastis filiformis, Scolecolepides viridus and Nereis succinea being most common. Amphipods (Corophium sp., Gammarus sp., Lepidactylus dytiscus, Leptocheirus plumulosus, and Monoculodes edwardsi) were also common at all sites, and molluscs (Macoma phenax and Macoma balthica) were occasionally important. Isopods and nemerteans were always minor components. At both non-vegetated areas, there were significant negative correlations between fish and infaunal biomass $(\mathrm{r}=-0.88$ and $-0.98, \mathrm{n}=6, \mathrm{p}$ $<0.05$ ), suggesting an important effect of fish predation on infaunal abundance (Summerson \& Peterson 1984). A similar, but weaker, relation was observed for the vegetated area at Todds Cove, but the correlation was not statistically significant for the Parsons Island macrophyte bed, possibly because of the mitigating effects of alternate food sources for fish at this area.

Epiphytic faunal abundance and seasonal patterns were markedly different between the 2 vegetated areas (Fig. 8C). At Parsons Island epiphytic fauna established quickly after the emergence of macrophytes and then declined; at Todds Cove densities were relatively low through July and then increased through October. Seasonal trends of abundance in both areas paralleled respective infaunal abundances indicating that similar factors (e.g. fish predation) were involved in regulating abundance of both animal groups. There were also differences between sites in terms of species composition: at Parsons Island insect larvae (Chironomid sp.), isopods (Erichsonella attunate) and amphipods were dominant; at Todds Cove tanaids were also important but isopods were a minor component. Levels of abundance at both. sites were near the lower end of values reported for other areas (e.g. Marsh 1976, Menzie 1980).

Numerical abundance and biomass of the 6 mobile macroinvertebrate species collected were dominated by grass shrimp (Paleomonetes intermedius and $P$. pugio). Grass shrimp biomass for the vegetated area at
Todds Cove steadily increased from 3 to $39 \mathrm{~g} \mathrm{ww} \mathrm{m}^{-2}$ over the study period (Fig. 9). Shrimp biomass was similar to that observed for the entire fish community. Neither total shrimp biomass nor weight per individual were correlated with macrophyte biomass, in contrast

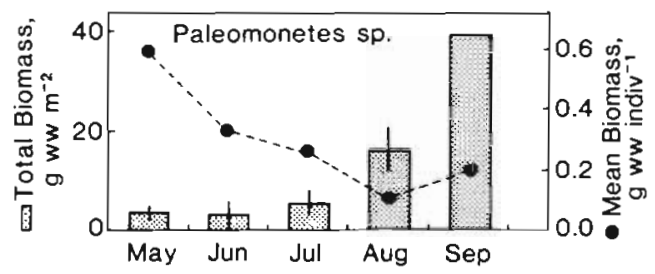

Fig. 9. Total biomass ( $g$ ww $\mathrm{m}^{-2} ; \overline{\mathrm{x}} \pm \mathrm{SE}$ ) and mean size ( $\mathrm{g} w \mathrm{w}$ individual $\left.{ }^{-1}\right)$ of Paleomonetes $\mathrm{sp}$. collected with a push-net from the vegetated area at Todds Cove. Entries without SE bars were based on either 1 or 2 samples

to reports for a vegetated site in southern Chesapeake Bay (Heck \& Orth 1980b). However, it is clear that grass shrimp exhibited a strong affinity for vegetated areas because, with one minor exception, they were not found at non-vegetated areas. Mean weight per individual shrimp decreased sharply from late spring through the summer as young shrimp recruited into the portion of the population sampled.

\section{Food habits versus resources}

The results of 'selectivity coefficient' (SC) calculations indicated that Menidia menidia and Leiostomus xanthurus were relatively non-selective $(\mathrm{SC} \leq 1.0)$ in their diets at the Parsons Island non-vegetated area, feeding primarily on the dominant infaunal organism groups in direct proportion to their relative availabilities. For example, polychaetes comprised approximately $60 \%$ of both the infaunal biomass (Kemp et al. 1983b) and the diets (Fig. 7) of both fishes, while molluscs and amphipods accounted for the remaining 30 and $10 \%$, respectively, of the infauna community, and roughly 5 to 10 and 5 to $15 \%$ of fish stomach contents.

Although polychaetes and molluscs comprised most of the combined infaunal plus epiphytic biomass, epiphytic material dominated the stomach contents for most of the fish examined at the vegetated area. Insect larvae, isopods, bryozoans and fish eggs, which occurred primarily in the epiphytic community, were important in the diets of all fish, and in many cases, fish were highly selective in their consumption of these organisms. For example, the SC's were about 3.5 for Menidia menidia consumption of insects and 10 for small Anguilla rostrata feeding on isopods. This preference for epiphytic, as opposed to infaunal prey items, 
has been attributed to the greater accessibility of epiphytic items to fish (Whitfield 1988).

Results of 'index of fullness' (FI) calculations indicated that for the species examined (those in Fig. 7) there were consistantly higher values of FI in fish from the vegetated versus non-vegetated areas at Parsons Island (Table 2). The most dramatic differences were for Apeltes quadracus and Fundulus heteroclitus, which had 5 to 15 times as much food in their stomachs from the macrophyte habitat. Fish for this analysis were sampled at the same time of day at both areas. Unless the diel feeding behaviors were substantially different for the same species at the 2 areas, observed variations indicated by the FI probably are real differences in feeding activity and success, which in turn reflect differences in food availability.

\section{Fish production}

An estimate of the adequacy of epiphytic and infaunal food supplies for fish in vegetated areas was developed by estimating production rates for these invertebrate groups using $\mathrm{P}: \mathrm{B}$ (production:biomass) ratios (Mann 1982, Valiella 1984) and comparing these results to production rates of the fish community (Table 3). Production rates for fish and epiphytic fauna at both vegetated areas were similar, but rates for infauna were in order of magnitude greater. Although some piscivory was evident among fish, most were feeding at a trophic level one step higher than that of the inver- tebrates. Assuming a $10 \%$ trophic efficiency for this system infaunal production alone would have been adequate to support growth of the fish community. Epiphytic fauna, which were a preferred food of fish in the macrophyte beds, were evidently more accessible and appeared to provide an important nutritional supplement for fish.

Direct production calculations were made for 6 fish species in the vegetated habitat and 5 at the nonvegetated area (Table 4). For most species, rates varied over the course of the study but tended to be highest in the June-July period, which corresponds to the time of maximum primary productivity, especially in the macrophyte habitat (Kemp et al. 1984). Summed production of the 5 fish species for which rates could be calculated at both sites was almost $50 \%$ higher in the vegetated than in the non-vegetated habitat (Table 4). Summed biomass for these species was actually lower in the macrophyte bed, so that the increased production was largely attributable to higher instantaneous growth rates (Kemp et al. 1984). This was particularly true for Menidia menidia and $M$. beryllina, for which production was most strongly enhanced in the vegetated area. It is, however, perplexing why Leiostomus xanthurus production was higher in the reference area. Assuming a water content of $80 \%$ (Royce 1972), total fish production for the macrophyte habitat would be equivalent to $0.8 \mathrm{~g} \mathrm{dw} \mathrm{m}^{-2} \mathrm{yr}^{-1}$ (Table 4), a value which is close to the rates calculated above by applying a $\mathrm{P}: \mathrm{B}$ ratio to the mean biomass values (Table 3 ). These rates are considerably higher than those previously reported for sev-

Table 2. Summary of percent stomach and gut fullness data $(\bar{x} \pm S E)$ for selected fish species collected at vegetated and nonvegetated areas at the Parsons Island study site in early summer (June). n: no stomachs and guts examined; -: species not encountered

\begin{tabular}{|c|c|c|c|c|c|c|c|}
\hline \multirow{3}{*}{$\begin{array}{l}\text { Species } \\
\text { Leiostomus xanthurus }\end{array}$} & \multirow{3}{*}{$\begin{array}{c}\begin{array}{c}\text { Size class } \\
(\mathrm{mm})\end{array} \\
35-84\end{array}$} & \multicolumn{3}{|c|}{ Vegetated area } & \multicolumn{3}{|c|}{ Non-vegetated area } \\
\hline & & $\mathrm{n}$ & Stomach & Gut & $\mathrm{n}$ & Stomach & Gut \\
\hline & & 7 & $34 \pm 13$ & $58 \pm 21$ & 10 & $28 \pm 5.3$ & $29 \pm 5.4$ \\
\hline Menidia menidia & $30-64$ & 14 & $37 \pm 12$ & $36 \pm 14$ & 13 & $27 \pm 19.0$ & $21 \pm 11.0$ \\
\hline Apeltes quadracus & $15-35$ & 10 & $72 \pm 13$ & $45 \pm 28$ & 6 & $5 \pm 1.4$ & $12 \pm 4.2$ \\
\hline Fundulus diaphanus & $15-40$ & 7 & $26 \pm 17$ & $39 \pm 18$ & 8 & $6 \pm 6.6$ & $17 \pm 7.5$ \\
\hline Morone americana & $100-200$ & 4 & $40 \pm 28$ & $25 \pm 28$ & - & - & - \\
\hline Anguilla rostrata & $100-200$ & 6 & $33 \pm 3.5$ & $20 \pm 14$ & - & - & - \\
\hline
\end{tabular}

Table 3. Comparison of mean biomass $\left(B_{;} g\right.$ dry $\left.w t \mathrm{~m}^{-2}\right)$ and estimated production $\left(\mathrm{P}_{;} \mathrm{dry} w t \mathrm{~m}^{-2} \mathrm{y}^{-1}\right.$ ) rates in vegetated areas for fish and potential infaunal and epifaunal food sources for June to September. Biomass values (ash-free) for epifauna, infauna and fish are from Kemp et al. (1983). Production values, which assume most of the growth occurs in the summer, are based on $P$ : B ratios compiled in Mann (1982) and Valiela (1984), where: epifauna $=1.8$; infauna $=1.3 ;$ fish $=0.7$

\begin{tabular}{|lcccccccc}
\hline $\begin{array}{l}\text { Sampling } \\
\text { area }\end{array}$ & B & Epifauna & & & Infauna & & Fish \\
\hline Parsons Island & 0.33 & & B & 0.60 & 8.4 & 10.9 & 0.85 & B \\
Todds Cove & 0.25 & 0.45 & 7.2 & 9.4 & 1.23 & 0.60 \\
\hline
\end{tabular}


Table 4. Summary of fish production estimates for selected species from vegetated and non-vegetated sampling areas at the Parsons Island study site. Mean biomass ( $\mathrm{g}$ wet wt $\mathrm{m}^{-2}$ ) and production ( $\mathrm{g}$ wet $\mathrm{wt} \mathrm{m}^{-2} 3 \mathrm{mo}^{-1}$ ) estimates are for the period $15 \mathrm{June}$ to 15 September Production estimates were made using the methods of Ricker (1971) where P = G $\times$ B (P: production; $G$ : instantaneous growth coefficient; B: average biomass). Year classes were determined from examination of length-frequency plots of each species. Totals include only those species and/or year classes for which estinates were available at both sites

\begin{tabular}{|c|c|c|c|c|c|}
\hline \multirow[t]{2}{*}{ Species } & \multirow[t]{2}{*}{ Yr class } & \multicolumn{2}{|c|}{ Vegetated site } & \multicolumn{2}{|c|}{ Non-vegetated site } \\
\hline & & B & $\mathrm{P}$ & B & $\mathrm{P}$ \\
\hline \multirow[t]{2}{*}{ Leiostomus xanthurus } & 0 & 0.86 & 1.25 & 1.38 & 2.26 \\
\hline & 1 & 0.30 & 0.53 & - & - \\
\hline Menidia menidia & 0 & 0.87 & 2.49 & 0.23 & 0.13 \\
\hline Menidia beryllina & 1 & 0.10 & 0.34 & 0.11 & 0.03 \\
\hline \multirow[t]{2}{*}{ Fundulus diaphanus } & 0 & 0.02 & 0.04 & - & - \\
\hline & 1 & 1.09 & 0.63 & - & - \\
\hline Apeltes quadracus & 0 & 0.08 & 0.10 & 0.003 & 0.001 \\
\hline Anchoa mitchilli & 0 & 0.08 & -0.11 & 0.65 & 0.41 \\
\hline Totals & & 1.99 & 4.07 & 2.37 & 2.83 \\
\hline
\end{tabular}

eral littoral zone fish communities (Adams 1976a, Weinstein 1979, Homer et al. 1980, Thorman \& Fladvad 1981).

During the late 1960 's to early 1970 's there was a precipitous decline in the proportion of littoral areas of Chesapeake Bay supporting submersed vascular plant communities, particularly in the lowest salinity reaches of the mainstem and tributary rivers (Orth \& Moore 1983). During the same period there were declines in commercial catches of several estuarine spawning species and increases in catches of several marine spawning species. Cause-effect linkages for these changes have not been clearly demonstrated but overfishing and declining water quality have often been mentioned. Given what has been learned about vegetated littoral areas it seems reasonable to also include the loss of vegetated littoral zone habitats as a contributor to changing fishery yields.

Acknowledgements. The following people contributed substantially to the successful completion of this study: S. Bunker, K. Kaumeyer and S. Staver were the principals in collection and laboratory processing of field data; the comments of 2 anonymous reviewers were particularly useful; E. B. Dawson and F. Younger drafted the figures; J. Pharis and J. Gilliard typed the manuscript. This work was supported primarily by a grant from the Environmental Protection Agency's Chesapeake Bay Program (Grant No. R8059322010).

\section{LITERATURE CITED}

Adams, S. M. (1976a). The ecology of eelgrass, Zostera marine (L.), fish communities. I. Structural analysis. J. exp. mar Biol. Ecol. 22: 269-291

Adams, S. M. (1976b). Feeding ecology of eelgrass fish communities. Trans. Am. Fish. Soc. 105: 514-519

Bell, J. D., Harmelin-Vivien, M. L. (1982). Fish fauna of French
Mediterranean Posidonia oceanica seagrass meadows. I. Community structure. Téthys 10:337-347

Bell, J. D., Harmelin-Vivien, M. L. (1983). Fish fauna of French Mediterranean Posidonia oceanica seagrass meadows. II Feeding habits. Téthys 11: 1-14

Bell, J. D., Westoby, M. (1986). Abundance of macrofauna in dense seagrass is due to habitat preference, not predation. Oecologia (Berl.) 68: 205-209

Brook, I. M. (1977). Trophic relationships in a seagrass community (Thalassis testudinum), in Card Sound, Florida. Fish diets in relation to macrobenthic and cryptic faunal abundance. Trans. Am. Fish. Soc. 106: 219-228

Burchmore, J. J., Pollard, D. A., Bell, J. D. (1984). Community structure and trophic relationships of the fish fauna of an estuarine Posidonia australis seagrass habitat in Port Hacking, New South Wales. Aquat. Bot. 18: 71-87

Carr, W. E. S., Adams, C. A. (1973). Food habits of juvenile marine fishes occupying seagrass beds in the estuarine zone near Crystal River, Florida. Trans. Am. Fish Soc. 102: $511-540$

Cyr, H., Downing, J. A. (1988). Empirical relationships of phytomacrofaunal abundance to plant biomass and macrophyte bed characteristics. Can. J. Fish. Aquat. Sci. 45: 976-984

Gray, C. A., Bell, J. D. (1986). Consequences of two common techniques for sampling vagile macrofauna associated with the seagrass Zostera capricorni. Mar Ecol. Prog. Ser. 28: $43-48$

Harmelin-Vivien, M. L. (1983). Etude comparative del'ichtyofaune des herebiers de phanerogrames marines en milieux tropical et tempere. Terre Vie 38: 200-206

Hartman, R. D., Herke, W. H. (1987). Relative selectivity of five coastal marsh sampling gears. Contr. mar. Sci. Univ. Tex. 30: $17-26$

Heck, K. L., Jr, Orth, R. J. (1980a). Seagrass habitats: the role of habitat complexity, competition and predation in structuring associated fish and macroinvertebrate assemblages. In: Kennedy, $V$ (ed.) Estuarine perspectives. Academic Press, New York, p. 449-464

Heck, K. L. Jr, Orth, R. J. (1980b). Structural components of eel grass (Zostera marina) meadows in the lower Chesapeake Bay - Decapod crustaceans. Estuarnes 3: 289-295 
Heck, K. L., Jr, Thoman, T A. (1984). The nursery role of seagrass meadows in the upper and lower reaches of the Chesapeake Bay. Estuaries 7.70-92

Hellier, T R., Jr (1962). Fish production and biomass studies in relation to photosynthesis in the Laguna Madre of Texas Publs Inst. mar Sci. Univ. Tex. 8: 1-22

Hildebrand, S. F., Schroeder, W C. (1928). Fishes of Chesapeake Bay, Vol. 18, Part 1. U.S. Bureau Fish. Bull.

Homer, M. Boynton, W R. (1978). Stomach analysis of fish collected in the Calvert Cliffs region, Chesapeake Bay 1977. Final report, Maryland Power Plant Siting Program. Chesapeake Biological Laboratory ref. no. UMCEES 78 154-CBL, Solomons

Homer, M., Mihursky, J. A., Jones, P. (1980). Quantitative approaches towards characterizing estuarine fish populations and communities. In: Schaefer, R. H. (ed.) Proceedings 4th Ann. Meet., Potomac Chapter. Am. Fish Soc. Washington, p. 39-99

Homziak, J., Fonseca, M. S., Kenworthy, W. J. (1982). Macrobenthic community structure in a transplanted eelgrass (Zostera marina) meadow. Mar. Ecol. Prog. Ser. 9: 211-221

Huh, S.-H., Kitting, C. L. (1985). Trophic relationships among concentrated populations of small fishes in seagrass meadows. J. exp. mar. Biol. Ecol. 92: 29-43

Kemp, W. M., Boynton, W. R., Stevenson, J. C., Means, J. C., Twilley, R. R., Jones, T W. (eds.) (1983b). Submerged aquatic vegetation in upper Chesapeake Bay: studies related to possible causes of the recent decline in abund ance. U. S. Environmental Protection Agency. National Technical Information Service (NTIS), Springfield, Va.

Kemp, W. M., Boynton, W. R., Twilley, R. R., Stevenson, J. C. Ward, L. G. (1984). Influence of submersed vascular plants on ecological processes in upper Chesapeake Bay. In Kennedy, V S. (ed.) The estuary as a filter. Academic Press, New York, p. 367-393

Kemp, W. M., Twilley, R. R., Stevenson, J. C., Boynton, W. R. Means, J. C. (1983a). The decline of submerged vascular plants in upper Chesapeake Bay: summary of results concerning possible causes. Mar Technol. Soc. J. 17: 78-88

Kikuchi, T (1974). Japanese contributions on consumer ecology in eelgrass (Zostera marina L.) beds, with special reference to trophic relationships and resources in inshore fisheries. Aquaculture, Tokyo 4: 145-160

Kjelson, M. A., Colby, D. R. (1976). The evaluation and use of gear efficiencies in the estimation of estuarine fish abundance. In: Wiley, M. (ed.) Estuarine processes, Vol. II. Academic Press, New York, p. 416-424

Kjelson, M. A., Johnson, G. N. (1974). Description and evaluation of a long-haul seine for sampling fish populations in offshore estuarine habitats. In: Rogers, W A. (ed.) 28th Ann. Conf. SE Ass. Game Fish Comm., p. 171-179

Leber, K. M., Greening, H. S. (1985). Community studies in seagrass meadows: a comparison of two methods for sampling macroinvertebrates and fishes. Fish. Bull. U.S. 84: $433-451$

Lewis, F. G., Stoner, A. W (1983). Distribution of macrofauna within seagrass beds: an explanation of patterns of abundance. Bull. mar. Sci. 33: 296-304

Livingston, R. J. (1982). Trophic organization of fishes in a coastal seagrass system. Mar Ecol. Prog. Ser. 7: 1-12

Mann, K. H. (1982). Ecology of coastal waters. Univ. California Press, Berkeley

Marsh, G. A (1976). The Zostera epifaunal community in the York River, Virginia. Chesapeake Sci. 14: 87-97

Menzie, C. A. (1980). The Chironomid (Insecta: Diptera) and other fauna of a Myriophyllum spicatum L. plant bed in the lower Hudson River. Estuaries 3: 38-54
Orth, R. J. (1973). Benthic infauna of eelgrass, Zostera marina beds. Chesapeake Sci. 14: 258-269

Orth, R. J., Heck, K. L., Jr (1980). Structural components of eelgrass (Zostera marina) meadows in the lower Chesapeake Bay-Fishes. Estuaries 3: 278-288

Orth, R. J., Heck, K. L., Jr, Montfrans, J. van (1984). Faunal communities in seagrass beds: a review of the influence of plant structure and prey characteristics on predator-prey relationships. Estuaries 7: 339-350

Orth, R. J., Moore, K. A. (1983). Chesapeake Bay: an unprecedented decline in submerged aquatic vegetation. Science 222: 51-53

Pollard, D. A. (1984). A review of ecological studies on seagrass - Fish communities, with particular reference to recent studies in Australia. Aquat. Bot. 18: 3-42

Ricker, W. E. (1971). Methods for assessment of fish production in freshwaters. IBP Handbook No. 3. Blackwell Science Publishers, Oxford

Robblee, M. B., Zieman, J. C. (1984). Diel variation in the fish fauna of a tropical seagrass feeding ground. Bull. mar. Sci. 34: $335-345$

Robertson, A. I. (1977). Ecology of juvenile King George whiting Sallaginodes punctatus (Cuvier and Valenciennes) (Pisces; Perciformes) in Western Port, Victoria. Aust. J. mar. Freshwat. Res. 28: 35-43

Robertson, A. I. (1980). The structure and organization of an eelgrass fish fauna. Oecologia 47: 76-82

Robertson, A. I. (1984). Trophic interactions between the fish fauna and macrobenthos of an eelgrass community in Western Port, Victoria. Aquat. Bot. 18: 135-153

Royce, W. F. (1972). Introduction to fisheries science Academic Press, New York

Rozas, L. P., Odum, W. E. (1987). Fish and macrocrustacean use of submerged plant beds in tidal freshwater marsh creeks. Mar Ecol. Prog. Ser. 38: 101-108

Rozas, L. P., Odum, W E. (1988). Occupation of submerged aquatic vegetation by fishes: testing the roles of food and refuge. Oecologia (Berl.) 77: 101-106

Savino, J. F., Stein, R. A. (1982). Predator-prey interactions between largemouth bass and bluegills as influenced by simulated, submersed vegetation. Trans. Am. Fish. Soc. 111: $255-266$

Serafy, J. E., Harrell, R. M., Stevenson, J. C. (1988). Quantitative sampling of fishes in dense vegetation: design and field testing of portable 'pop-nets' J. appl. Ichthyol. 4: 149-157

Sogard, S. M., Powell, G. V. N., Holmquist, J. G. (1987). Epibenthic fish communities on Florida Bay banks: relations with physical parameters and seagrass cover Mar. Ecol. Prog. Ser. 40: 25-39

Stoner, A. W. (1980). The role of seagrass biomass in the organization of benthic macrofaunal assemblages. Bull. mar. Sci. 30: 537-551

Stoner, A. W. (1983). Distribution of fishes in seagrass meadows: role of macrophyte biomass and species composition. Fish. Bull. U.S. 81: 837-842

Summerson, H. C., Peterson, C. H. (1984). Role of predation in organizing benthic communities of a temperate-zone seagrass bed. Mar. Ecol. Prog. Ser 15: 63-77

Thayer, G. W., Fonseca, M. S. (1984). The ecology of eelgrass meadows of the Atlantic Coast: a community profile. U. S. Fish Wildl. Serv. FWS/OBS-84/02

Thorman, S., Fladyad, B. (1981). Growth and production of fish in river Broalven Estuary on the Swedish West coast. Nat. Swedish Environ. Prot. Bd. Rep. 1416, Stockholm

Valiela, I. (1984). Marine ecological processes. Springer-Verlag, New York 
Ward, L. G., Kemp, W. M., Boynton, W R. (1984). The influence of waves and seagrass communities on suspended particulates in an estuarine embayment. Mar. Geol. 59: 85-103

Weinstein, M. P. (1979). Shallow marsh habitats as primary nurseries for fishes and shellfish, Cape Fear River, North Carolina. Fish. Bull. U. S. 77: 339-349

Weinstein, M. P. (1983). Population dynamics of an estuarinedependent fish, the spot (Leiostomus xantharus), along a tidal creek-seagrass meadow coenocline. Can. J. Fish. Aquat. Sci. 40: 1633-1638

Weinstein, M. P., Brooks, H. A. (1983). Comparative ecology of nekton residing in a tidal creek and adjacent seagrass

This article was submitted to the editor meadow: community composition and structure. Mar. Ecol. Prog. Ser 12: 15-27

Whitfield, A. K. (1984). The effects of prolonged aquatic macrophyte senescence on the biology of the dominant fish species in a southern African coastal lake. Estuar coast. Shelf Sci. 18: 315-329

Whitfield, A. K. (1988). The fish community of the Swartvlei Estuary and the influence of food availability on resource utilization. Estuaries 11: 160-170

Wiley, M. J., Gordon, R. W., Waite, G. W., Powless, T (1984). The relationships between aquatic macrophytes and sport fish production in Illinois ponds: a simple model. Am. J. Fish. Mgmt 4: 111-119

Manuscript first received: May 25, 1989

Revised version accepted: March 13, 1990 